\title{
Pension Accounting: Funding Costs And Liabilities of Corporate Pension Plans
}

\author{
Dr. Fawzi G. Dimian, Accounting, University of Minnesota, Duluth \\ Ms. Linda L. Kahlbaugh, Research Assistant, University of Minnesota, Duluth
}

\begin{abstract}
Overall, pension plan assets analyzed in this study appear strong. They have excellent overall funding and unfunded vested liabilities would require less time to fund currently than in 1978. Pension expense per employee have been increasing, but at very nominal rates. And although the companies with the highest profits may not be the companies with the highest pension expenses, average pension expenses for most categories decreased. Currently unfunded vested liabilities are low relative to both pre-tax profits and net worth. Again, a number of points should be kept in mind when looking at these analysis and trends. Industry categories had small sample sizes. The sample sizes increase when companies are lumped into ranking categories making the data more representative. The overall trends include sample sizes of approximately 90, an acceptable number for statistical analysis. Also, some of the trends could be clouded by definitions of assets, liabilities, and income which differ from the 1978 study. However, after examining basic similarities between the studies and noting the strength of certain trends, the above mentioned conclusions appear warranted.
\end{abstract}

\section{Statement of the Problem:}

Pensions represent a major economic force in our society. This is clearly evident from the magnitude of pension plan assets from which pension benefits are paid. In 1975 private pension plans covered 27.7 million individuals, paid benefits of $\$ 16$ billion, and had assets of $\$ 211$ billion. Pension plan assets have been a growing component of the U.S. economy during the past 50 years and their asset level now exceeds $\$ 2.3$ trillion, according to a report released by the Employee Benefit Research Institute (EBRI) in 1989. The amount of total equity and bonds in the economy held by pension funds has increased substantially since 1950 . At the end of 1988 , private and public pension funds together held $25 \%$ of total equity in the economy ( $\$ 768$ billion) and $15 \%$ of taxable bonds ( $\$ 703$ billion). In 1950 pension funds held only $.8 \%$ of total equity and $3.2 \%$ of taxable bonds (EBRI,1989). It is also estimated that by 1995 such pension plans will cover 44.5 million individuals, pay benefits of $\$ 106$ billion, and have assets in excess of $\$ 2.5$ trillion. Pension plans are a type of long-term commitment with some special characteristics not found in other types of liabilities. The result is that corporations have a legal liability to fund vested benefits, regardless of any pension contract clauses to the contrary (Wolk et al., 1989). Non-vested benefits are a liability on fair or equitable grounds. However, this point is marginally supported from an accounting standpoint (Wolk et al., 1989). The accounting issues are related to measuring the pension liability in terms of vested and nonvested benefits and plan assets.

\section{The Nature of Pension Expense and Liability}

Perhaps the two most controversial issues related to pension accounting are matching pension expense with revenue, and more importantly, measuring and disclosing pension liabilities. The following discussion is limited to defined benefit plans and addresses only normal service cost when referring to pension expense. The defined benefit pension is an exchange transaction between the employer and the employee. In exchange for services provided by the employee, the employer promises to provide, beside wages and other benefits, an amount of retirement income.

The expense recognition issue arises from the nature of pensions. They are a form of compensation. In exchange for the services of the employee, a company agrees to provide continued payments to the employee after the employee retires. Since the benefits are earned over the service period of the employee, the pension expense should be recognized and allocated over the same period. 
Although the idea is simple, the allocation process is difficult. The expense allocation problem for the accountant is to select a method of measuring benefits earned by employees during the current period taking into consideration possible future conditions including: future wage increases, length of expected service, and the recipients life expectancy.

The Employee Retirement Income Security Act (ERISA) of 1974 confirmed the existence of a liability. ERISA made annual funding payments mandatory. In addition, the Pension Benefit Guaranty Corporation requires that sponsoring companies fund certain vested benefits up to specified minimum amounts. Furthermore, Statement of Financial Accounting Concepts No. 6 defines accounting liabilities as "... probable future sacrifices of economic benefits arising from present obligations ..." Once benefits vest, there is a formal obligation between the employer and the employees as set out in the terms of the plan. The result is that corporations have a legal liability to fund vested benefits, regardless of any pension contract clauses to the contrary. However, non-vesting benefits as a liability is marginally supported from an accounting standpoint. Since existence of an obligation is no longer debatable, the accounting problem is to measure the liability taking into consideration vested and non-vested benefits and plan assets.

\section{Accounting Under Statement of Financial Accounting Standards No. 87}

SFAS No. 87 is an attempt to make pension accounting practices more congruent with theory regarding expense and liability recognition. The opinion was completely phased in as of December 15, 1988, and has an asset/liability approach rather than the revenue/expense approach of APB No.8 "Accounting for the Cost of Pension Plans". The most significant feature of this opinion is its independent measurements of expense and liability. Furthermore, the pension benefit obligation of the employer is the actuarial present value of future pension benefits for employee services rendered up to the measurement date for a particular year. The Statement defines and uses two different pension benefit obligations. The accumulated benefit obligation includes vested benefits and non-vested benefits based on current and past compensation levels. Meanwhile, the projected benefit obligation is based on assumptions about future compensation levels of employees. The relationship between these obligations is illustrated as follows (Welsch et al., 1986):

\begin{tabular}{lc} 
Vested benefits & $\mathrm{xxx}$ \\
Nonvested benefits & $\mathrm{xxx}$ \\
\cline { 2 - 2 } Accumulated benefit obligation & $\mathrm{xxx}$ \\
$\begin{array}{l}\text { Effect of estimated future } \\
\text { compensation levels }\end{array}$ & $\mathrm{xxx}$
\end{tabular}

Projected benefit obligation $\quad \mathrm{xxx}$

Pension expense is based only on employee service rendered to date. Under this new rule, companies can not delay pension expense to future periods and to use a uniform method for computing pension expense rather than selecting from several equally acceptable alternatives.

The opinion also narrowed the range of actuarial assumptions used in computing the pension expense. Companies can fund as expense is recorded or on any other actuarial basis which meet minimum ERISA requirements. Narrowing the choice to one does not allow management the room to manipulate net income and the comparability of inter-firm statements is enhanced.

Liability measurement is independent from the expense measurement. The additional minimum liability recognized is, at a minimum, the difference between plan assets and accumulated benefits as shown in the diagram. An intangible asset for the same amount will be recognized to the extent of prior service cost not yet recognized. If the additional liability exceeds unrecognized prior service cost, the excess would be reported as a reduction of equity. The FASB justifies the recognition of an intangible asset because it represents future expected economic benefits (increased productivity, lower turnover, etc.) to the employer. Any funding pattern can be used and is reflected in plan assets. The expense and liability are related only because they are both based on the same actuarial method. However, the expense includes amounts based on expected future salary increases which is not included in the liability measurement. This difference is recognized when it becomes an actual liability of the company through employee service. As a result, the liability is based only on services rendered to date and matches the definition of a liability. Clearly, SFAS No. 87 is an improvement over APB No. 8 in its independent measurement of the liability. Although SFAS No. 87 should enhance comparability and more fairly indicate a firm's pension liability, it could encounter resistance. The selection of the projected benefits method is claimed to be arbitrary and its superiority assumed. (Wolk et al., 1989) However, this argument is weak. The prescribed cost method measures amounts which fit expense and liability definitions. Another criticism is that the liability includes amounts which are non-vesting. Inclusion of this on the balance sheet could distort its meaning, be misunderstood, and have adverse economic consequences. Also, the minimum liability entry creates a new asset on the balance sheet which is not consistent with the definition of an asset.

Another major obstacle with the opinion could be with discount rates. Use of certain interest rates are suggested but not required under the new rules. As a result, rates can be changed which then alters the expense and liability 
recognition. Debra P. Walker, 1984 in the Georgia Journal of Accounting stated that," The general rule of thumb is that a one percent change in the interest rate affects pension costs for a given year by $25 \%$. The precise effect of the interest rate assumption depends to a large extent on its interaction with the other actuarial assumptions." Net income could still be manipulated and liabilities, once again, eliminated from the balance sheet. Furthermore, the statement does not offer a meaningful statements and fails to help readers of the financial statements. The main disadvantage of the new pension standards is the tendency to change the net periodic pension cost annually for no substantive reason. The application of Statement No. 87 did not significantly narrow the range of assumptions used to compute pension expense and obligations (Stone and Ingram, 1988). All these issues are controversial.

While several years may pass before the overall effects of SFAS No. 87 can be understood, an initial assessment can be made of the reporting changes which will take place. The authors conducted an empirical research study as an attempt to measure the balance sheet effect for 100 companies from "Fortune 500". Specifically, to measure the additional minimum liability to be recorded under SFAS No. 87 as a percent of net worth. As a result, if the balance sheet ratios would be significantly affected and if it would result in a shift in wealth between stockholders and debt holders. Secondly, this analysis focuses on the financial position of pension plans as measured by funding levels, expense levels, and their relationship to net income and net worth. Most of this analysis was fashioned after a study published in 1979 by Johnson \& Higgins entitled, Funding Costs and Liabilities of Large Corporate Pension Plans. While this previous study covers a consecutive two-year period:1977 and 1978 for 475 of the Fortune 500 Industrial Corporations, the current study covers only one: 1986 for 100 of the Fortune 500 Industrial Corporation. For comparison purposes, we will quote where ever pertinent the related results from Johnson \& Higgins' study.

\section{Data Extracted from the Annual Reports}

For analysis, we used 10 items from the 1986 annual reports. These items and their definitions are as follows:

Income From Operations: Revenue from the main activities of the business less cost of sales and operation expenses.

Income From Continuing Operations: Income from operations plus other interest and income less other interest and expense; this also includes non-recurring items, equity income, minority interest, and taxes.

Total Net Income: Reported net income which is the sum of income from continuing operations, income from discounted operations, and extraordinary items.

Total Assets, Total Liabilities, and Shareholders' Equity: Reported with the following adjustments: (1) Deferred tax credit and debits were omitted. (2) Mandatory redeemable preferred stocks were classified as liability. (3) Minority interest on the balance sheet was included with the liabilities.

Pension Expense, Net Plan Assets, Vested Benefits, and Unvested Benefits: Each were taken directly from the footnotes disclosed in the annual reports with no adjustments.

Comparisons made with the prior study are approximate. There may be some differences between the two studies in the income or expense measurements used. Also, for certain groupings the sample size on which averages were computed was decreased sharply from 1979 to the current study. These differences should be considered when making comparisons over time.

\section{Minimum Liability Recorded Under SFAS No. 87 as a Percent of Net Worth}

As the accompanying table indicates, the additional minimum liability for the companies studied would be

\section{Company Selection}

This study extracted data from the 1986 annual reports to shareholders of companies selected on the basis of three criteria: (1) The number of companies chosen from each Fortune 500 industry was the same proportion in the sample of 100 as in the 500 ranking. (2) Each company headquartered in Minnesota was automatically included. (3) The remaining companies were chosen evenly throughout the industry based on their asset ranking within that industry.

\begin{tabular}{|c|c|c|c|c|c|}
\hline & & \multicolumn{2}{|c|}{$\begin{array}{c}\text { Minimum Liability to be Recorded } \\
\text { Under SFAS No. } 87 \\
\text { as a Percent of Net Worth } \\
\text { (Summary by Industry Ranking) }\end{array}$} & \multirow[b]{2}{*}{$\begin{array}{l}\text { Minimum } \\
\text { Liability } \\
\text { per FASB No.87 } \\
(000 \text { 's })\end{array}$} & \multirow[b]{2}{*}{$\begin{array}{c}\text { Min. } \\
\text { as a \% } \\
\text { Net Worth }\end{array}$} \\
\hline Ranking & & $\begin{array}{c}\text { Number } \\
\text { of } \\
\text { Companies }\end{array}$ & $\begin{array}{l}\text { Net Worth } \\
\text { (000's) }\end{array}$ & & \\
\hline $1-100$ & 25 & $\$ 345,608,623$ & & $(\$ 3,521,000)$ & $1.02 \%$ \\
\hline $101-200$ & 14 & $33,716,368$ & & $(\$ 790,132)$ & $2.34 \%$ \\
\hline $201-300$ & 12 & $12,447,863$ & & $(\$ 9,356)$ & $0.08 \%$ \\
\hline $301-400$ & 16 & $10,443,441$ & & $(\$ 26,900)$ & $0.26 \%$ \\
\hline $401-500$ & 16 & $5,761,013$ & & $\$ 0$ & $0.00 \%$ \\
\hline Total & 83 & $\$ 407,977,308$ & & $(\$ 4,347,388)$ & $1.07 \%$ \\
\hline
\end{tabular}


immaterial at approximately $1.07 \%$. The effect on the ratios would not be significant. Stockholders and creditors would not encounter setbacks from the initial adoption of the standard. The same conclusion was reached by Stone and Ingram in their research study in 1988 in that "the initial balance sheet impact of Statement No.87 was minimal."

\section{Average Pre-tax Income and Average Pension Expense}

The largest companies increased their share of total Fortune 500 profits while the smaller companies supported a greater proportion of the pension expense. Surprisingly, the average pre-tax profits for only the Fortune 100 category and for all groups taken together increased as table 1 shows; each other Fortune 500 ranking category decreased in average pre-tax profits, the $301-400$ and $401-500$ groups by half. The total average increased from $\$ 285$ million in 1979 to \$357 million in 1986.

The data presented in table 2 shows that pension expense somewhat paralleled average pre-tax profits. The expense went down for all ranking categories except the 101-200 group. The total average increased over time from $\$ 35.7$ to $\$ 47.3$ million.

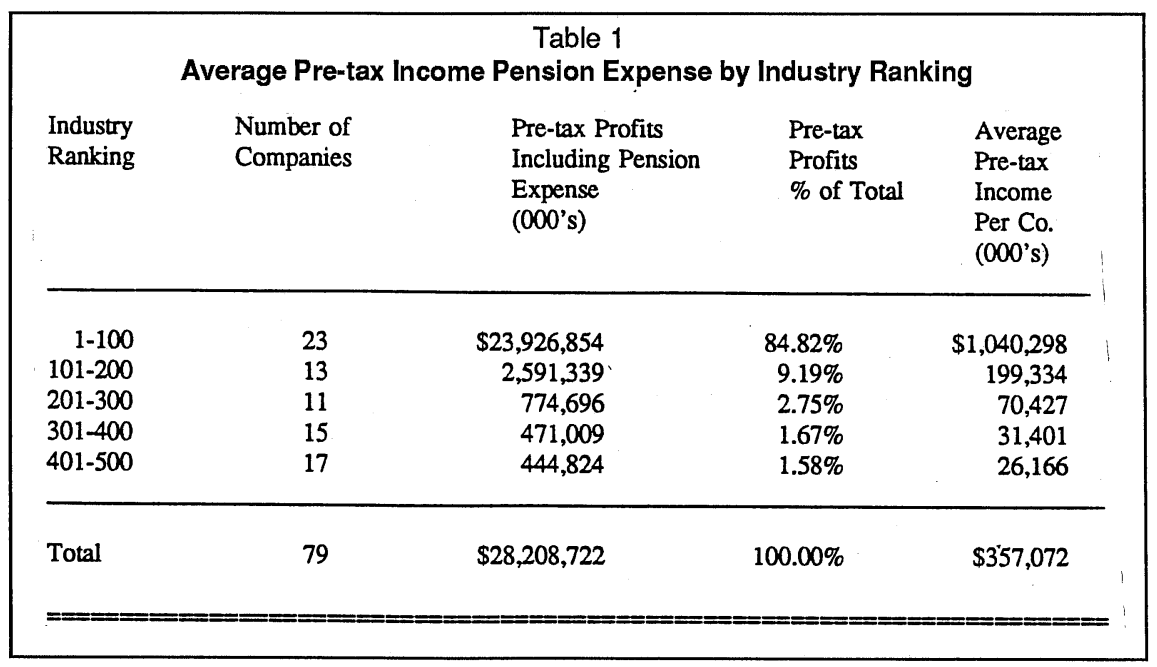

\begin{tabular}{|c|c|c|c|c|}
\hline \multicolumn{5}{|c|}{ Table 2} \\
\hline $\begin{array}{l}\text { Industry } \\
\text { Ranking }\end{array}$ & $\begin{array}{l}\text { Number of } \\
\text { Companies }\end{array}$ & $\begin{array}{c}\text { Pension } \\
\text { Expense } \\
(000 \text { 's })\end{array}$ & $\begin{array}{l}\text { Pension } \\
\text { Expense } \\
\% \text { of Total }\end{array}$ & $\begin{array}{c}\text { Average } \\
\text { Pension } \\
\text { Expense } \\
\text { Per Co. } \\
(000 \text { 's })\end{array}$ \\
\hline $1-10$ & 23 & $\$ 2,521,433$ & $67.50 \%$ & $\$ 109,628$ \\
\hline $101-200$ & 13 & 956,878 & $25.62 \%$ & 73,606 \\
\hline $201-300$ & 11 & 96,269 & $2.58 \%$ & 8,752 \\
\hline $301-400$ & 15 & 90,583 & $2.42 \%$ & 6,039 \\
\hline $401-500$ & 17 & 70,296 & $1.88 \%$ & 4,135 \\
\hline Total & 79 & $\$ 3,735,459$ & $100.00 \%$ & $\$ 47,284$ \\
\hline
\end{tabular}

The profits as a percent of total profits for each industrial ranking group did not parallel the pension expense as a percent of total pension expense. The largest companies increased their share of profits relative to pension expense more than the smaller companies which proportionately supported more of the expense.

\section{Pension Expense Per Employee}

The overall average pension expense per employee increased nominally from $\$ 1,100$ in 1979 to $\$ 1,187$ in 1986, approximately $1 \%$ per year. In the 1979 study, each industry average and each industrial ranking average increased between 1978 and 1979. In the 1986 study the industrial changes were mixed. This carried through to the rankings with the $0-100,201-300$, and $401-500$ categories decreasing and the 101-200 and 301-400 increasing. This trend may indicate that employers are trying to cut back on their pension expense per employee.

\begin{tabular}{|c|c|c|c|}
\hline \multicolumn{4}{|c|}{$\begin{array}{c}\text { Pension Expense Per Employee } \\
\text { (Raw Data Sorted by Industry Grouping) }\end{array}$} \\
\hline & $\begin{array}{l}\text { Industry } \\
\text { f Companies }\end{array}$ & & $\begin{array}{l}\text { Industry } \\
\text { Average }\end{array}$ \\
\hline & Aerospace & 4 & $\$ 1,276$ \\
\hline & Apparel & 1 & 357 \\
\hline & Beverages & 1 & 1,090 \\
\hline & Building Materials & 4 & 534 \\
\hline & Chemicals & 7 & 1,097 \\
\hline & Computers & 5 & 539 \\
\hline & Electronics & 7 & 819 \\
\hline 8 & Food & 10 & 705 \\
\hline 9 & Forest Products & 7 & 764 \\
\hline 0 & Furniture & 1 & 103 \\
\hline 1 & Industrial \& Farm Eq. & 5 & 927 \\
\hline 2 & Jewelry, Silverware & 1 & 239 \\
\hline 3 & Metal Products & 2 & 1,230 \\
\hline 4 & Metals & 3 & 1,258 \\
\hline 5 & Mining, Crude-Oil Prod. & 3 & 1,720 \\
\hline 16 & Motor Vehicles \& Parts & 1 & 385 \\
\hline 17 & Petroleum Refining & 6 & 1,181 \\
\hline 18 & Pharmaceutical & 1 & 21,986 \\
\hline 19 & Publishing, Printing & 2 & 1,084 \\
\hline 20 & Rubber Products & 2 & 2,433 \\
\hline 21 & Scientific \& Photo Equ. & 3 & 1,036 \\
\hline 22 & Soaps, Cosmetics & 1 & 760 \\
\hline 23 & Textiles & 1 & 0 \\
\hline 24 & Tobacco & 1 & 877 \\
\hline 25 & Toys, Sporting Goods & 1 & 177 \\
\hline 26 & Transportation Eq. & 0 & 0 \\
\hline
\end{tabular}




\section{Pension Expense as a Percent of Income From Operations}

In this analysis, we considered pension expense an administrative expense and added it to income. Overall, pension expense as a percent of income from operations ranged from $0 \%$ to $85 \%$ with two companies reporting pension income due to changes in plan reporting methods. The average pension expense for all companies was $9.9 \%$ of income from operations; 55 of 79 companies had percentages under $10 \%, 5$ were greater than $30 \%$, two of which were over $50 \%$. No similar analysis in the 1979 study was done on income from operations preventing a comparison over time. No similar analysis in the 1979 study was done on income from operations preventing a comparison over time. increased over 1979. The largest increases were a 55.3 and 13.7 straight percentage point increases for the 401500 and 101-200 groups. Each current category is within $5 \%$ points of the prior study as shown in the following table.

\begin{tabular}{llcc} 
& & & $\begin{array}{c}\text { \% change } \\
\text { over 1979 }\end{array}$ \\
\hline $0-9.9 \%$ & $45 \%$ & $40 \%$ & $(.11)$ \\
$10-19.9 \%$ & 32 & 30.7 & $(.04)$ \\
$20-29.9 \%$ & 13 & 17.3 & .33 \\
$30-39.9 \%$ & 3 & 5.3 & .77 \\
$40-49.9 \%$ & 2 & 1.3 & $(.35)$ \\
$50 \%$ \& over & 3 & 5.3 & .77 \\
\hline
\end{tabular}

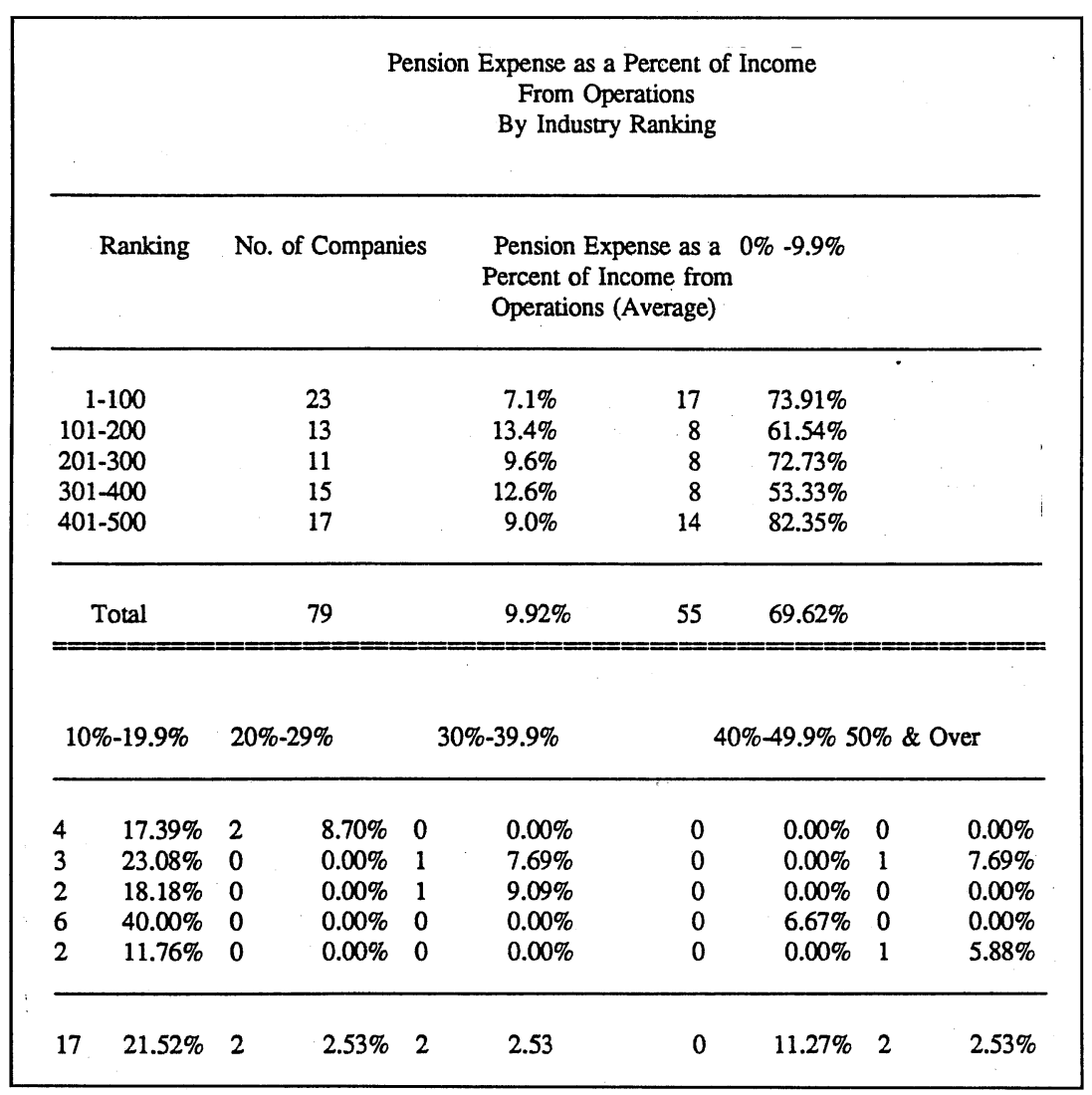

While in 1977 and 1978 approximately one and one half months profit was required to cover pension expense, approximately two month's profits was needed in 1986. While a one half month increase does not seem like much, absolute dollar values are astronomical, amounting to $\$ 1,175,360,000$.

\section{Unfunded Vested Liabilities as a Percent of Pre-tax Profits}

We will briefly look at one final aspect of pensions, the number of months of pretax profits needed to cover unfunded vested liabilities. This snapshot will be limited to industrial ranking. Terminated plans must now be fully funded to vested amounts. Current and prior years are shown below: (see page 73)

Again, current numbers show an improvement over 1979. The one group showing an increase, the 101-200 category, was also the group which supported a disproportional amount of pension expense relative to profits.

\section{Pension Expense as a Percent of Income from Continuing Operations}

\section{(Pre-tax Income Not Including Extra-ordinary Items)}

As in the last analysis, we added pension expense back to income before we calculated the pension expense as a percent of income from continuing operation. The results appropriately indicate the portion of pre-tax income apportioned to the benefits which are generally tax deductible. The average for all companies was $28.1 \%$.

Each of the ranking categories 1-100, 101-200, etc.,

\section{Unfunded Vested Liabilities as a Percent of Net Worth}

Unfunded vested liabilities as a percentage of net worth clearly showed an improvement over the last 8 years; for all companies taken together, the percentage dropped from 7.9 to 1.8. In addition, each industrial ranking category percentage decreased and 7 of 8 the 1978 industrial groups decreased their percentage. About 9.0\% showed no unfunded vested liabilities. Assuming this trend were consistent over a larger sample size, many of those companies showing unfunded vested liabilities are now show- 


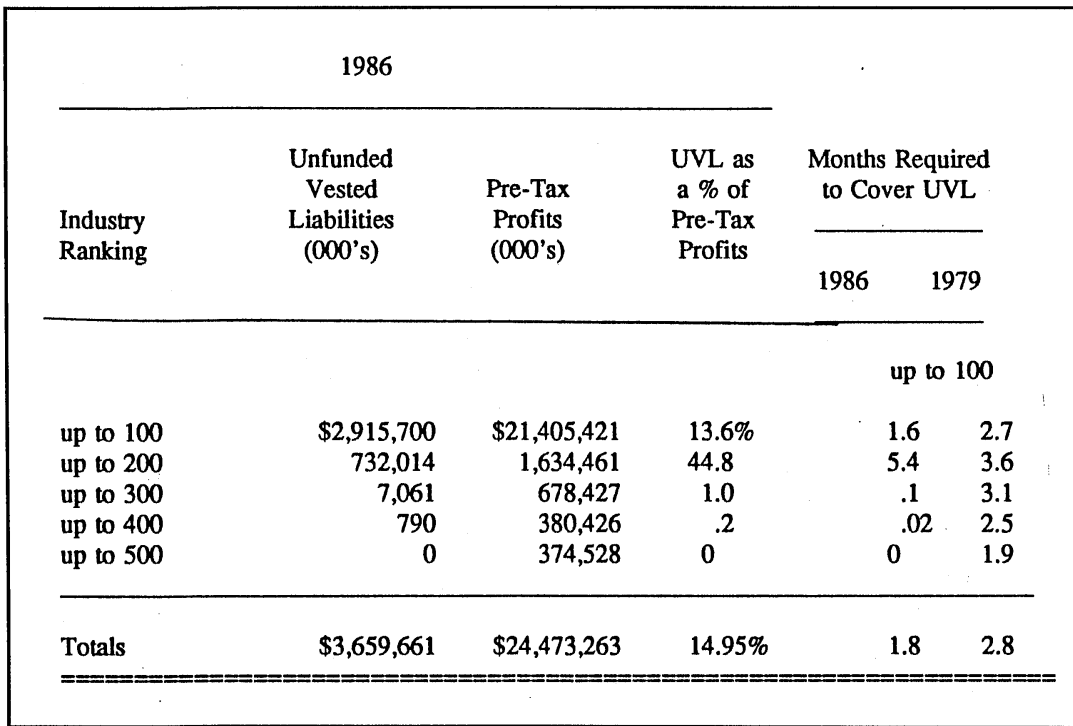

ing a zero liability. The comparison between 1978 and 1986 is as follows:

\begin{tabular}{lllllll}
\multicolumn{8}{c}{ UVL= } \\
$\begin{array}{llllll}\text { UVL as a \% } \\
\text { of NET Worth }\end{array}$ & 0 & $.1-9.9 \%$ & $10-19.9 \%$ & $20.29 .9 \%$ & $>30 \%$ \\
\hline 1978 & $7.9 \%$ & $26 \%$ & $48 \%$ & $16 \%$ & $5 \%$ & $6 \%$ \\
1986 & 1.8 & 91 & 2.5 & 2.5 & 0 & 3.8
\end{tabular}

The trend appears to be decreasing with respect to net worth. Although this seems to be an improvement, this could be due to a number of factors. The market in which pension funds are invested has been strong over the last several years. In addition, actuarial assumptions and methods are allowed to be changed from year to year. The result is that the underlying assumptions in these numbers may be difficult to compare over time and between companies. The influence of the possible changes are unknown. However, this trend does appear extremely favorable.

\section{Plan Assets as a Percent of Vested Benefits}

Discussion has just been centered around how well corporation have funded their plans relative to the net worth of the reporting company. A different ratio will be looked at which reverses the unfunded vested liabilities as a percentage of net worth ratio, a more direct measure.

Plan assets increased by $343 \%$ from $\$ 247.9$ to $\$ 1097.2$ million. The overall picture is outstanding with pensions $143 \%$ funded. The majority of companies fall in the 100 to $175 \%$ range.

Each industrial ranking category increased, the lowest being a 37 percentage point jump. In addition, all but three of the industrial groupings increased from between 20 and $117 \%$ points.

\section{Conclusion}

Results obtained in the 1979 study by Johnson \& Higgins on pension costs for 475 of the Fortune 500 Industrial Corporations indicated that pension costs do not constitute a major burden or financial drain for most large corporations and the fortune 500 Industrial Corporations. The cost of maintaining pension plans did not increase significantly during 1978. Their study also concluded that the majority of large corporate pension plans are adequately funded to provide promised benefits on an ongoing basis.

Overall, pension plan assets analyzed in this study appear strong. They have excellent overall funding and unfunded vested liabilities would require less time to fund currently than in 1978. Pension expense per employee have been increasing, but at very nominal rates. And although the companies with the highest profits may not be the companies with the highest pension expenses, average pension expenses for most categories decreased. Currently unfunded vested liabilities are low relative to both pre-tax profits and net worth. Again, a number of points should be kept in mind when looking at these analysis and trends. Industry categories had small sample sizes. The sample sizes increase when companies are lumped into ranking categories making the data more representative. The overall trends include sample sizes of approximately 90 , an acceptable number for statistical analysis. Also, some of the trends could be clouded by definitions of assets, liabilities, and income which differ from the 1978 study. However, after examining basic similarities between the studies and noting the strength of certain trends, the above mentioned conclusions appear warranted.

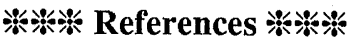

1. FASB,1985. Employers' Accounting for Pensions. Statement of Financial Accounting Standard No. 87.

2. FASB, 1985. Elements of Financial Statements. Statement of Financial Accounting Concepts No. 6.

3. Johnson \& Higgins. 1979. Funding Costs and Liabilities of Large Corporate Pension Plans. New York, N.Y. Johnson \& Higgins.

4. Stone, M., R.W. Ingram. 1988. "The Effect of Statement No. 87 on the Financial Reports of Early Adopters." Accounting Horizons (September):48-61.

5. Walker, D. P. 1984. "Pensions." Georgia Journal of Accounting.

6. Welsch, G.A.,and C.T. Zlatkovich.1989. Intermediate Accounting. Homewood, IL: Irwin.

7. Wolk, H. I., J. R. Francis, and M. G. Tearney. 1989. Accounting Theory: A Conceptual and Institutional Approach. Boston, MA PWS-KENT Publishing Co. 